\title{
AN ATTRACTIVE NEW BUT RARELY SEEN ODONTOGLOSSUM (ORCHIDACEAE: ONCIDIINAE) FROM ECUADOR
}

\author{
STIG DALSTRÖM \\ 2304 Ringling Boulevard, unit 119, Sarasota FL 34237, USA \\ Lankester Botanical Garden, University of Costa Rica, Cartago, Costa Rica \\ National Biodiversity Centre, Serbithang, Bhutan \\ stigdalstrom@gmail.com
}

\begin{abstract}
A new species of Odontoglossum from a limited area in western Ecuador is described, illustrated with a line drawing and color photographs, and compared with apparently closely related species, which are illustrated with color photographs. The new species differs from them all by a combination of features, such as the limited geographic distribution, frequently purple mottled pseudobulbs, a broadly pandurate lip lamina and widely spreading purple striped callus keels on the lip.
\end{abstract}

KeY words: new species, Cymbidieae, Epidendroideae, Ecuador.

History and discussion. The Odontoglossum Kunth species described here belongs to a rather confusing complex of a taxonomically challenging genus that is difficult to survey. The taxonomic difficulties are caused mainly by the notorious variability in floral structures, which most Odontoglossum species display. The reason for this variability can probably be discussed forever, but natural hybridization appears to be a strong factor, which may actually benefit this probably deceit pollinated group of plants. Odontoglossum species in general do not seem to offer any particular rewards to the pollinator other than possibly perfume, and the variability in terms of flower size and coloration may contribute to lure various bees to repeat visiting the often rather strongly scented flowers (Dalström, 2003). Species of Odontoglossum have been transferred to Oncidium by Chase and others (Chase et al. 2008). A justification for rejecting this treatment is explained in more detail elsewhere (Dalström 2012, 2014).

\section{Taxonomic treatment}

\section{Odontoglossum hirtzii Dalström, sp. nov.}

TYPE: Ecuador. Imbabura: Selva Alegre, alt. 2600 m, 29 Sept. 1984, A. Hirtz 1923 (holotype: Rio Palenque Science Center [MO], left specimen on sheet 0000748). Fig. 1.

Diagnosis. Odontoglossum hirtzii (Figs. 1-3), differs from the similar and locally sympatric $O$. armatum
Rchb.f. (Figs. 4,5 ) by a slightly larger overall size, a larger and pandurate lip with distinctly cordate to hastate basal angles of the lamina, much more developed purple-striped callus keels, and with considerably larger column wings, versus a more slender habit, a cuneate lip lamina with a less developed, generally plain white callus and insignificant or no column wings for O. armatum. Odontoglossum hirtzii is also superficially similar to $O$. cristatellum Rchf.b. (Fig. 6), O. cristatum Lindl. (Fig. 7) and O. furcatum Dalström (Fig. 8) but is readily distinguished from them by the distinctly pandurate lip lamina and commonly purple mottled pseudobulbs, versus a more cordate lamina for the latter species, which all have plain green to yellowish or sometimes reddish pseudobulbs without any mottling.

Epiphytic herb. Roots typical for the genus and spreading. Pseudobulbs caespitose, on a compact bracteate rhizome, ovoid to pyriform, apically obtuse, ancipitous and slightly compressed, commonly mottled with purple, unifoliate (on type, but bifoliate on larger plants), ca. $3.0 \times 1.5 \mathrm{~cm}$, subtended basally by 6 to 7 distichous sheaths, the uppermost foliaceous. Leaf subpetiolate, conduplicate, narrowly ovate, acute, $c a .8 .5 \times 1.8 \mathrm{~cm}$. Inflorescence, axillary from the base of the outermost sheath, erect and arching, to $c a .26 \mathrm{~cm}$ long, almost straight to loosely flexuous, $c a$. 8-flowered raceme; bracts appressed, scale-like, $c a$. $0.4-0.6 \mathrm{~cm}$ long. Pedicel and ovary ca. $2.5-3.0 \mathrm{~cm}$ 


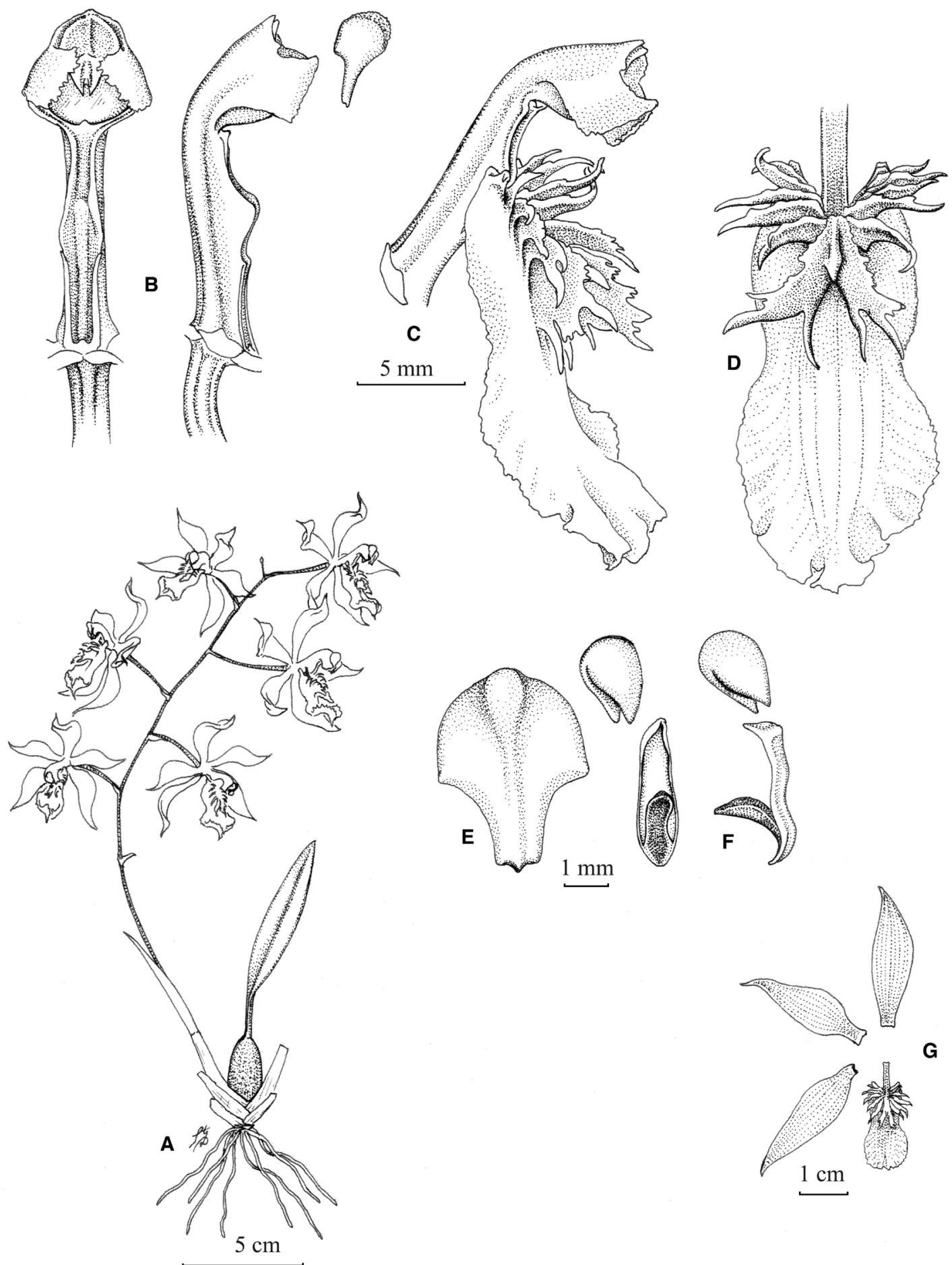

Figure 1. Odontoglossum hirtzii. A. Plant habit. B. Column, ventral and lateral views, with anther cap. C. Column and lip, lateral view. D. Lip, dorsal view. E. Anther cap, dorsal view. F. Pollinarium with one (of two) pollinia, ventral and lateral views. G. Flower dissected. Drawn from holotype by Stig Dalström. 


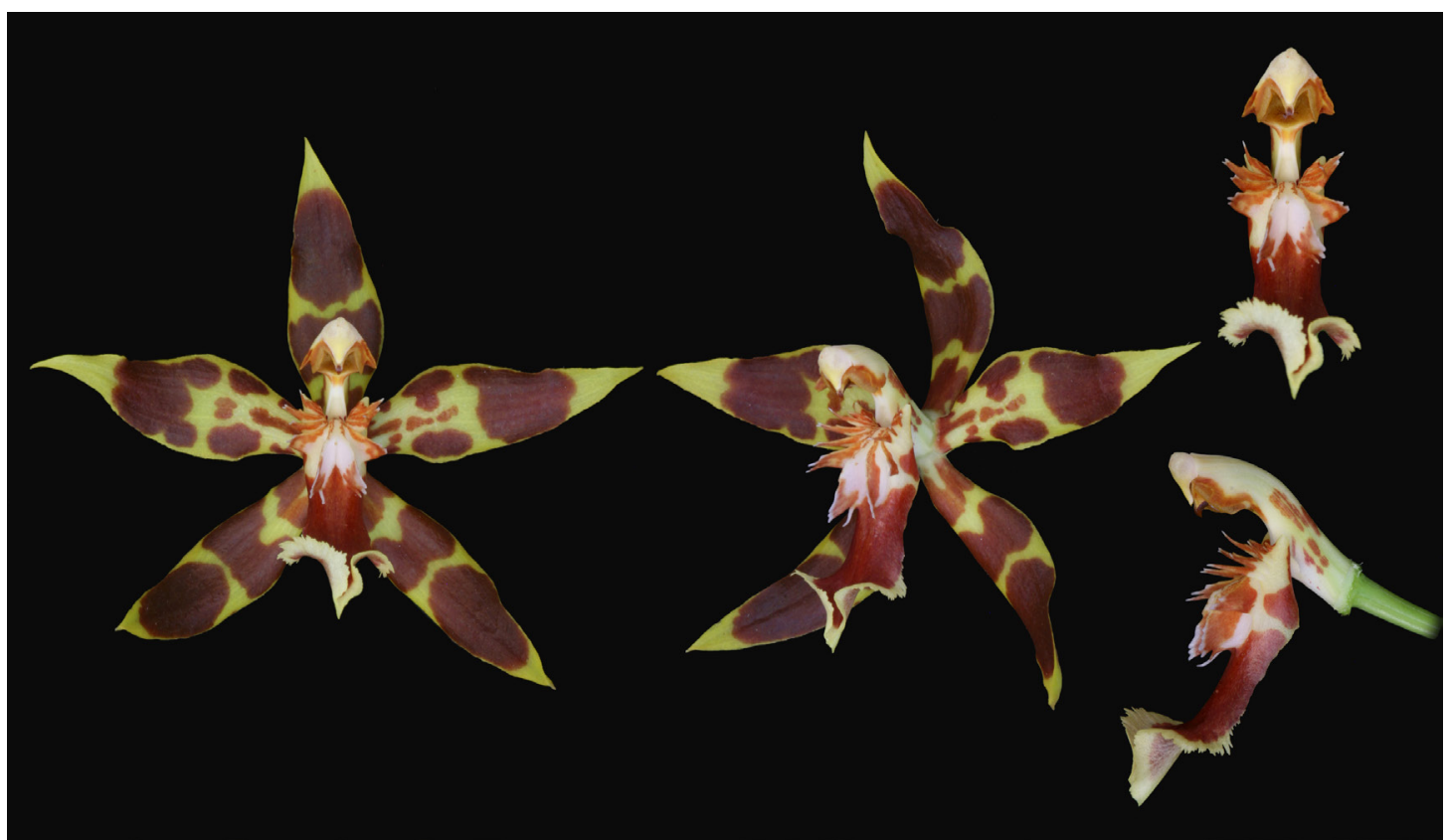

Figure 2. Odontoglossum hirtzii, G. Deburghgraeve 039 (Dalström archives). Photo by G. Deburghgraeve.

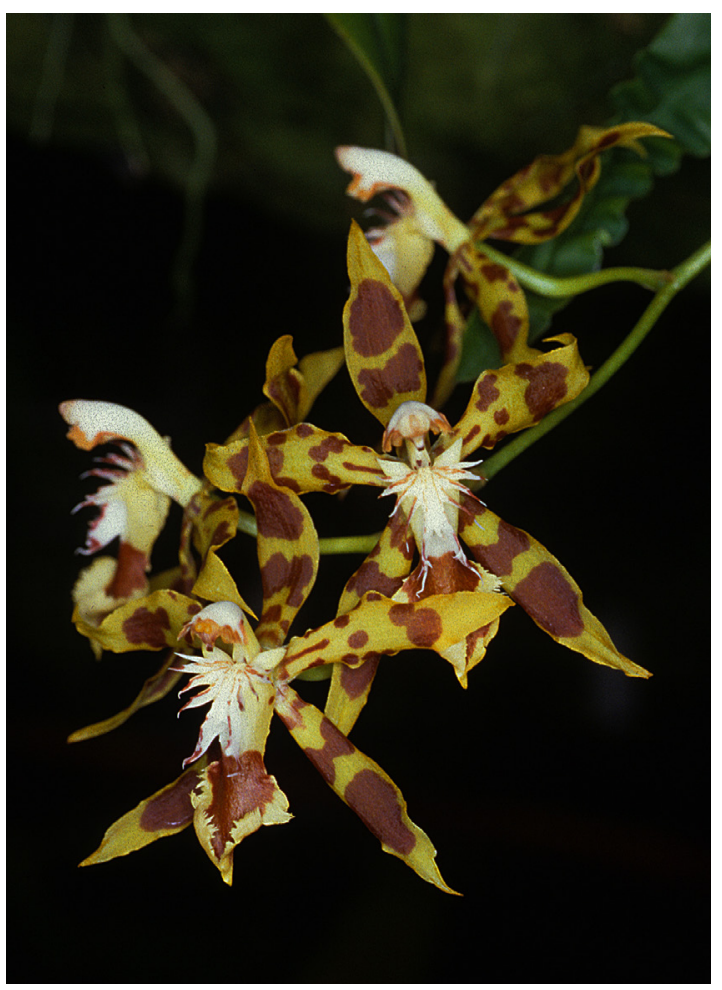

Figure 3. Odontoglossum hirtzii, Mindo, S. Dalström 3755 (color transparency; Dalström archives). Photo by S. Dalström. long. Flower stellate, showy; dorsal sepal chocolate brown with yellow markings, weakly unguiculate, elliptic-ovate, narrowly acute to acuminate, ca. $3.0 \times$ $0.9 \mathrm{~cm}$; lateral sepals similar in size and color, and slightly oblique; petals similar to the sepals in color, unguiculate, ovate, acuminate, to $c a .3 .0 \times 1.0 \mathrm{~cm}$; lip red-brown with a yellow margin, fused to the canaliculated ventral side of the column by a flat strap of tissue for ca. $4.0 \mathrm{~mm}$, then free and developing into a cordate to hastate pandurate, slightly undulate and serrate lamina, to $c a .2 .0 \times 1.0 \mathrm{~cm}$; callus white (fide Hirtz, but commonly spotted with purple) of well-developed radiating, gradually increasing in size, serrate to multifid and acute keels, emerging from the base of the canaliculated lamina; column color on type not described by Hirtz, but generally white with purple-brown spots, slender and erect, laterally weakly keeled, ventrally canaliculated with well-developed angles, and with a large rectangular and slightly serrate wing on each side of the stigmatic surface, ca. $1.5 \mathrm{~cm}$ long; anther cap color not described by Hirtz but commonly white to pale yellow, campanulate and angular rostrate, dorsally weakly lobulate; pollinarium of two cleft/folded pyriform pollinia on a narrowly elongate-ovate, ca. $3.0 \mathrm{~mm}$ long stipe, on a hooked, pulvinate viscidium.

LANKESTERIANA 15(1), April 2015. (C) Universidad de Costa Rica, 2015. 


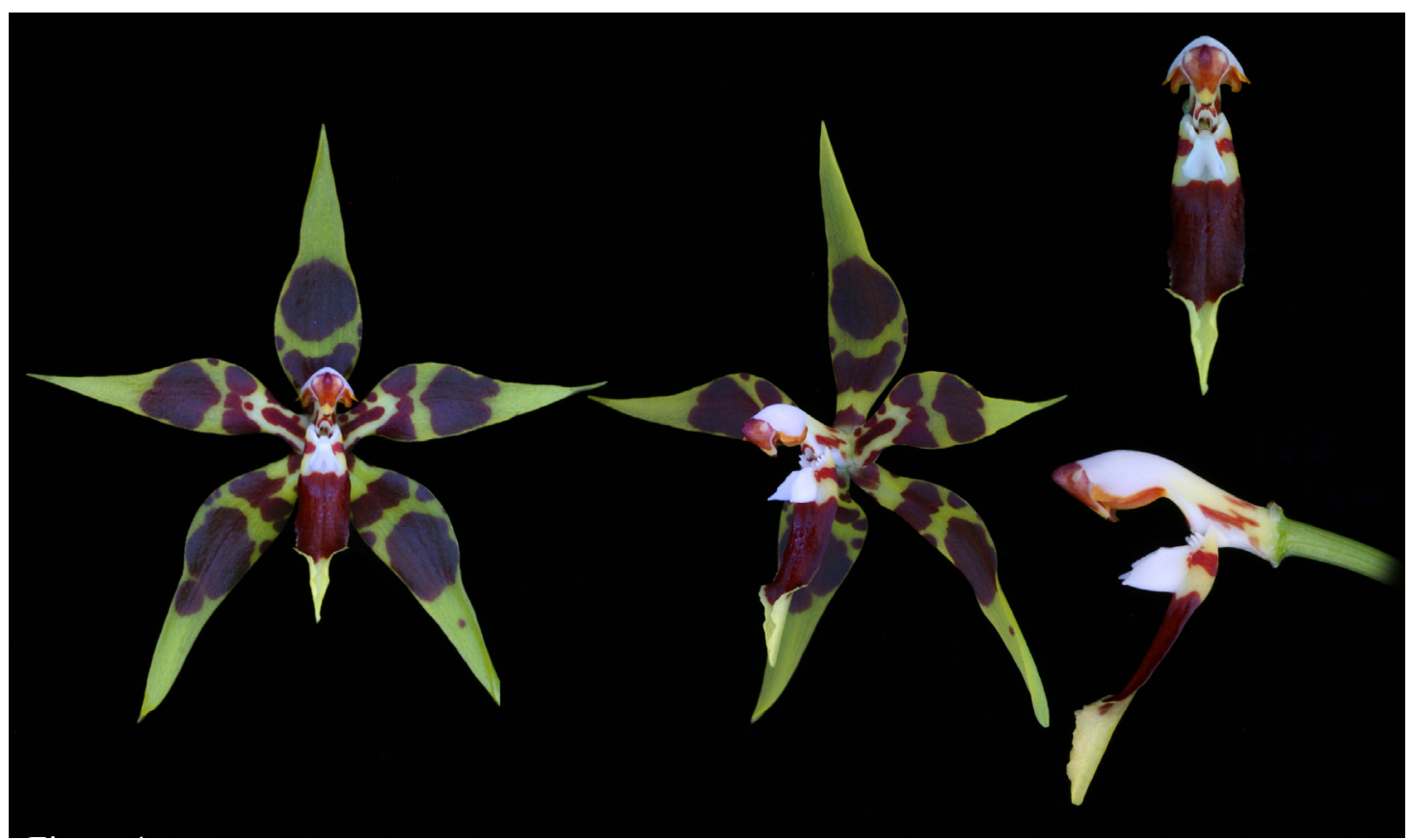

FIgURE 4. Odontoglossum armatum 'Rony'. Photo by G. Deburghgraeve.

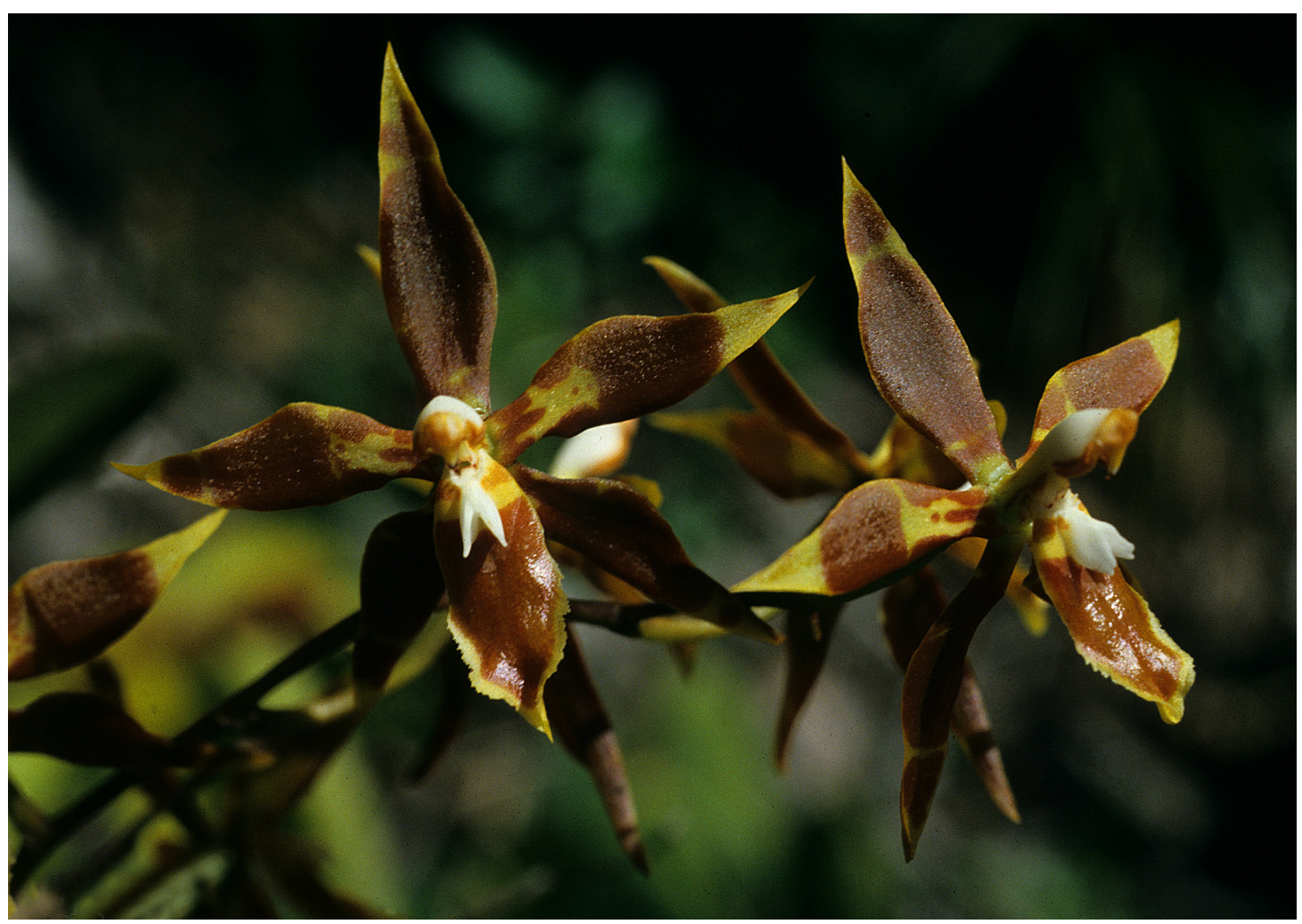

FIgURE 5. Odontoglossum armatum, Maldonado, S. Dalström 053 (flower in alcohol at SEL). Photo by S. Dalström. LANKESTERIANA 15(1), April 2015. (C) Universidad de Costa Rica, 2015. 


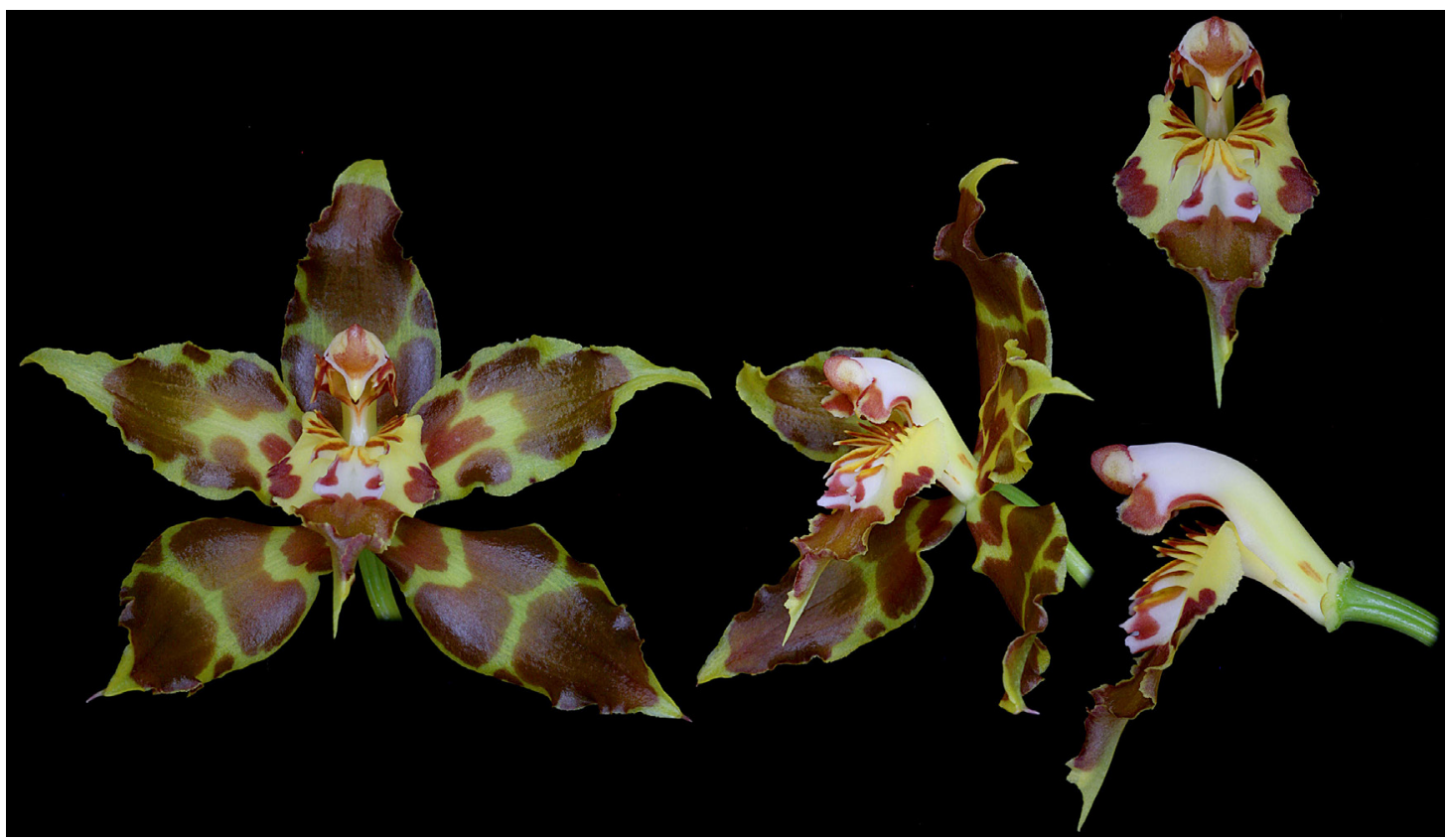

FIGURE 6. Odontoglossum cristatellum, plant cultivated and photographed by G. Deburghgraeve.

Odontoglossum hirtzii is an attractive and colorful little species that has been hiding in herbaria under different names or simply unidentified. It is also a very floriferous species that often produce two and sometimes even three inflorescences per growth. The purple mottling on the pseudobulb of $O$. hirtzii is a feature shared by the sympatric $O$. armatum, which speculatively may suggest that $O$. hirtzii has a hybrid origin, or evolved away from $O$. armatum at some time due to some genetic alterations. Odontoglossum cristatellum is not found near the area where $O$. hirtzii occurs and differs in having a more robust flower with a thicker column, while $O$. cristatum, which is not sympatric, and $O$. furcatum generally occur at lower elevations than $O$. hirtzii. Odontoglossum furcatum may possibly be sympatric with $O$. hirtzii where their distribution elevations meet but has larger flowers with a longer column ( $c a .20 \mathrm{~mm}$ versus $15 \mathrm{~mm}$ long for $O$. hirtzii) and different looking bi-furcated wings. Odontoglossum hallii Lindl. (Fig. 9) may superficially resemble $O$. hirtzii as well but is much larger in overall size (for example: sepals $5.0-6.0 \mathrm{~cm}$ long versus $c a$. $3.0 \mathrm{~cm}$ long for $O$. hirtzii) and the pseudobulbs lack the purple mottling, which is typical for $O$. hirtzii. Plants of Odontoglossum hirtzii have also been misidentified as Odontoglossum "denticulatum" [nomen nudum] by me in the past. This particular epithet was coined by Friedrich Lehmann, based on some of his collections from Nanegal, Ecuador (which, coincidently, corresponds with the known area for $O$. hirtzii), but was never officially described and therefore should not be used at all. After some lengthy analysis and comparisons between Lehmann's "denticulatum" and the type, and other collections, of $O$. armatum, the conclusion is that they represent the same species, and differ from the locally sympatric and rather similar $O$. hirtzii. The most distinct difference between the two can be seen in the size and shape of the column, and particularly the cordate to hastate base of the pandurate lip lamina, as well as the more developed and purplespotted lip callus of $O$. hirtzii. The impressive variability of the flower shape and size among plants of $O$. armatum, however, suggest that natural hybridization may be rather common, which, of course, blurs the species distinctions. Plants have been found by me and others that suggest several possible 'hybrid partners', such as a small-flowered form of $O$. mirandum Rchb.f. (O. reversum Bockem.), O. cristatellum Rchb.f., and possibly also $O$. aspidorhinum Lehm., which all occur sympatrically in northern Ecuador on the western 


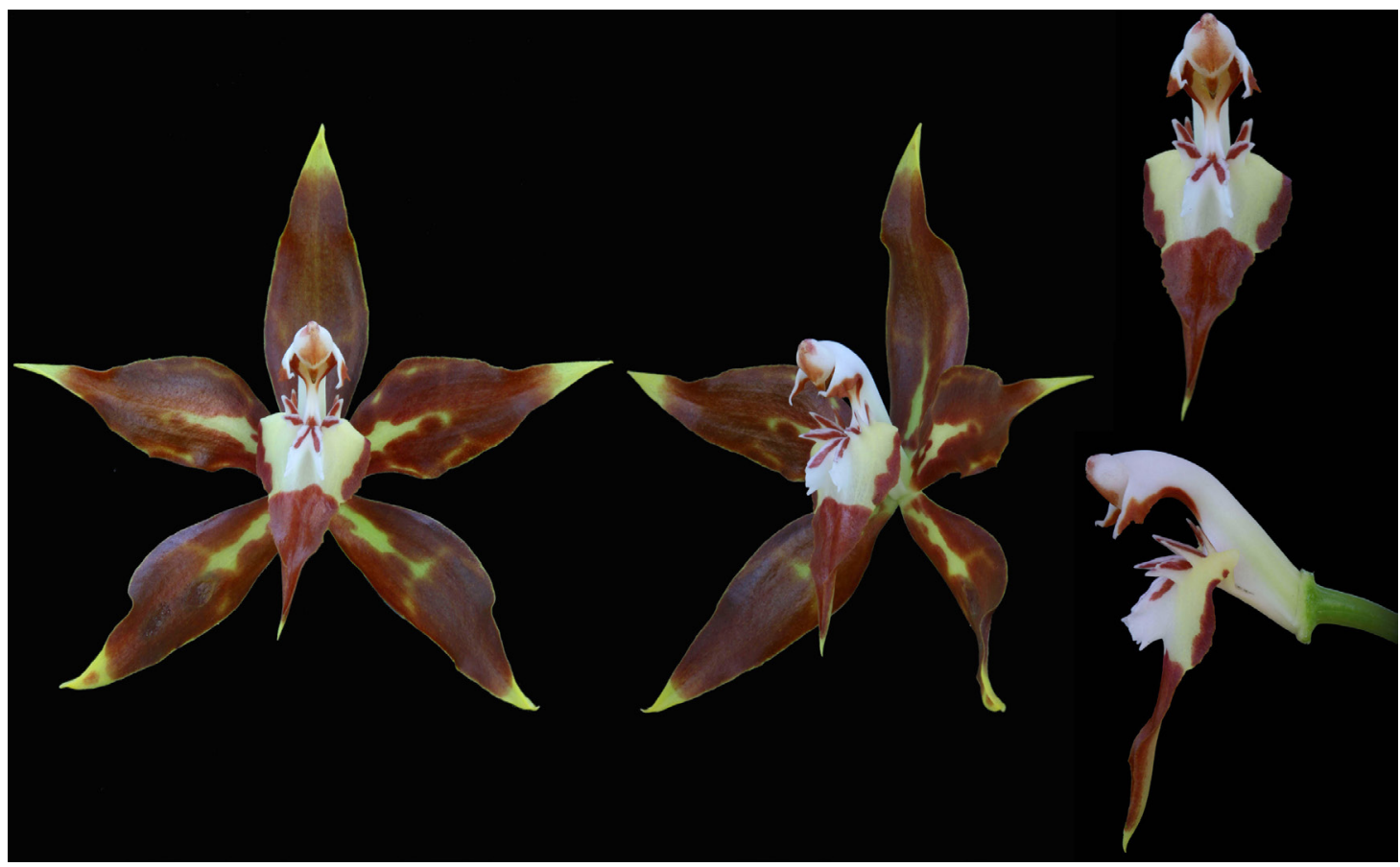

FIgURE 7. Odontoglossum cristatum, plant cultivated and photographed by G. Deburghgraeve.

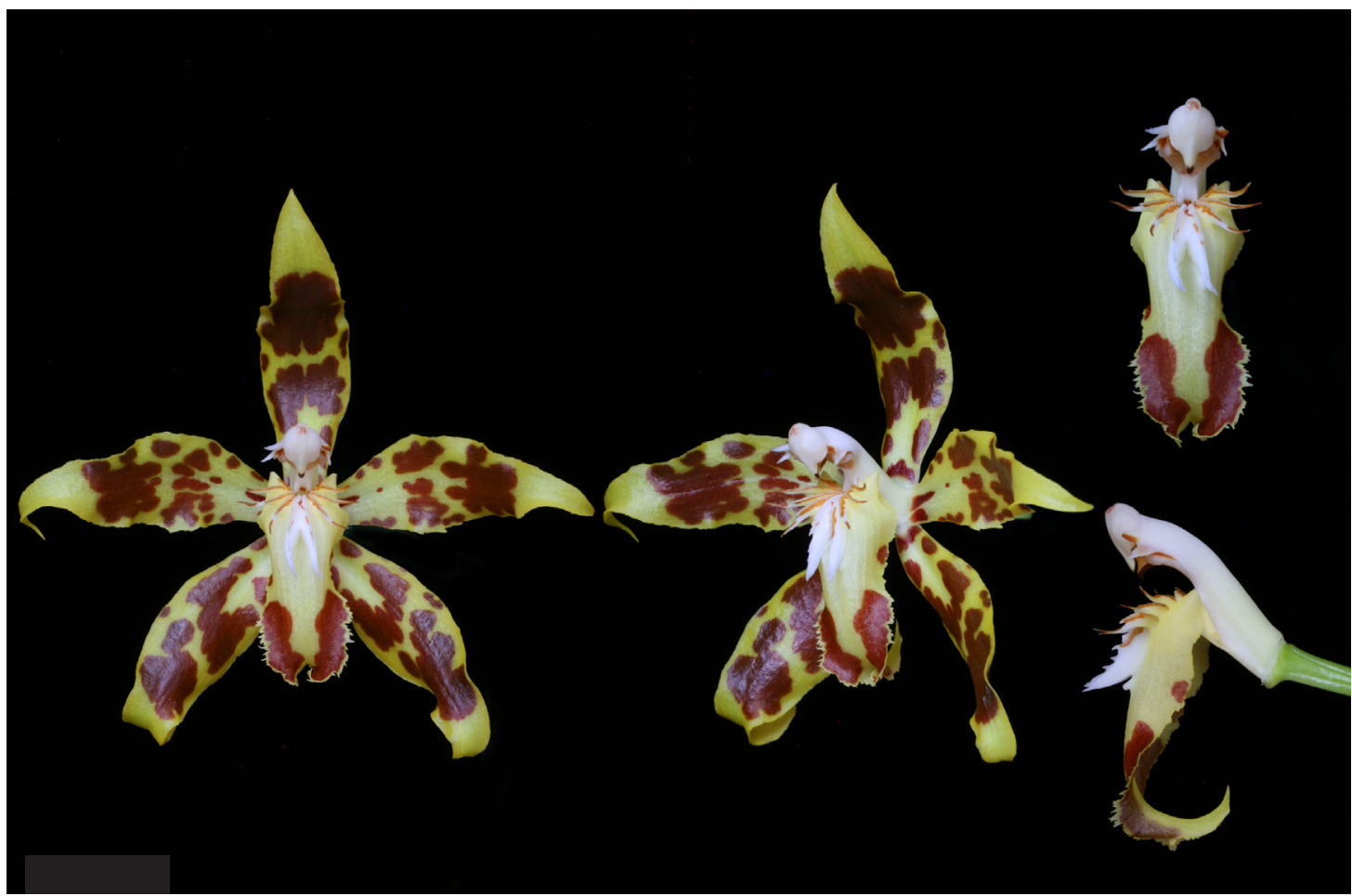

FIGURE 8. Odontoglossum furcatum, plant cultivated and photographed by G. Deburghgraeve. 


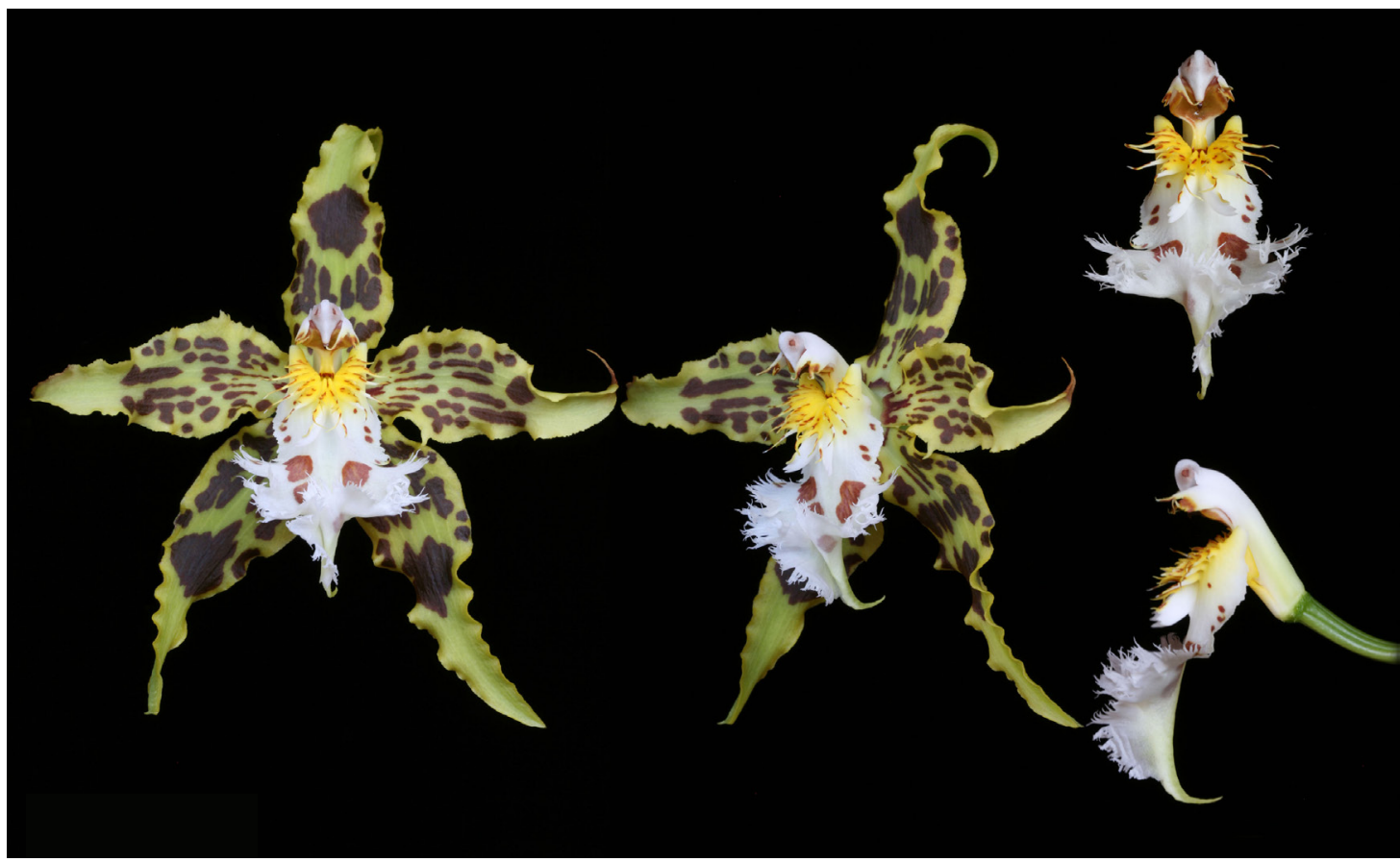

FIgURE 9. Odontoglossum hallii, plant cultivated and photographed by G. Deburghgraeve.

slopes of the Andes near the Colombian border. Only by repeating these suspected crosses in a controlled environment can these identity problems possibly be solved. No plants of Odontoglossum hirtzii have been seen by me or reported from this area though, and a sufficient number of plants with a sufficiently consistent morphology have been seen (in addition to the specimens cited below), to justify treating it as a valid species, honoring one of the world's greatest orchid discoverer.

AdDitional MATERIAL SEEN: Ecuador. Imbabura, "Otavalo", $2200-2500 \mathrm{~m}$, collected and flowered in cultivation by Ecuagenera, May 2004, S. Dalström 2490 (Dalström archives). Pichincha, Mindo, alt. 2000 - 2400 m, date unknown, A. Hirtz 031 (SEL). Same province, Canton Quito, Bosque Protector Maquipucuna, montane rain forest, crest and upper slopes of Cerro Monte Cristo, ca. $9 \mathrm{~km}$ airline SE of Nanegalito, $2700-2795 \mathrm{~m}, 00^{\circ} 03^{\prime} \mathrm{N}, 78^{\circ} 36^{\prime} \mathrm{W}$, 8-9 Sept. 1993, G. L. Webster et al. 30556 (DAV). Same province, Mindo, ca. 2200 - 2400 m, Jan. 1979, S. Dalström et al. 574 (color transparencyDalström archives). Same area, Feb. 1992, flowered in cultivation later same year, S. Dalström et. al. 3755 (color transparency-Dalström archives). Fig. 3. Same province, Tandayapa, along road Nono - Nanegal, alt. $2000 \mathrm{~m}$, collected and cultivated in Paute by A. Andreetta, 25 Feb. 1982, C. H. Dodson 12858 (SEL). Same area, 1800 [?] - 2200 m, Feb. 1982, A. Andreetta 0216 (SEL).

Distribution: Odontoglossum hirtzii is only known from, and probably endemic to the seasonally extremely wet cloud forests of the western slopes of the Andes in north-central Ecuador at elevations of $c a$. $2000-2800 \mathrm{~m}$.

EPONYMy: Named in honor of Alejandro "Alex" Hirtz, a mining engineer and prominent nature explorer of Quito, Ecuador, who has contributed more than anyone else to the discovery of new plants, and particularly orchids in his country.

AcKnOwLedGMENTS. I thank Wesley Higgins for reviewing and commenting on the manuscript, Guido Deburghgraeve for providing the descriptive color photographs, and the curators of the DAV, MO and SEL herbaria for providing opportunities to study the cited specimens. 


\section{LiTERATURE CITED}

Chase, M. W., Williams, N. H., Neubig, K. M. \& Whitten, W. M. (2008). Taxonomic transfers in Oncidiinae to accord with Genera orchidacearum. Lindleyana, 5, 20-31.

Dalström, S. (2003). Orchids smarter than scientists - an approach to Oncidiinae (Orchidaceae) taxonomy. Lankesteriana, 7, 33-36.

Dalström, S. (2012). New combinations in Odontoglossum (Orchidaceae: Oncidiinae) and a solution to a taxonomic conundrum. Lankesteriana, 12(1), 53-60.

Dalström, S. (2014). A new and striking Odontoglossum (Orchidaceae: Oncidiinae) from Peru. Lankesteriana, 13(3), 401405. 